\title{
Radiological Hazards for Marble and Granite Used at Shak El Thouban Industrial Zone in Egypt
}

\author{
Amany T. Sroor ${ }^{1}$, Saher M. Darwish ${ }^{2 *}$, Samia M. El-Bahi ${ }^{1}$, Mohamed G. Abdel Karim ${ }^{2}$ \\ ${ }^{1}$ Nuclear Physics Laboratory, Faculty of Girls, Ain Shams University, Cairo, Egypt; ${ }^{2}$ Physics Department, Faculty of Science, Cairo \\ University, Giza, Egypt. \\ Email: "saherm2001@yahoo.com
}

Received October $1^{\text {st }}, 2013$; revised October $31^{\text {st }}, 2013$; accepted November $28^{\text {th }}, 2013$

Copyright (C) 2013 Amany T. Sroor et al. This is an open access article distributed under the Creative Commons Attribution License, which permits unrestricted use, distribution, and reproduction in any medium, provided the original work is properly cited. In accordance of the Creative Commons Attribution License all Copyrights (C) 2013 are reserved for SCIRP and the owner of the intellectual property Amany T. Sroor et al. All Copyright (C) 2013 are guarded by law and by SCIRP as a guardian.

\begin{abstract}
The background level of radiation in the natural environment surrounds us at all times. Levels of natural occurring radioactivity in marble and granite used at Shak El Thouban industrial zone in Cairo, Egypt have been investigated using HPGe detector through gamma-ray spectrometry. The activity concentration of radionuclides in the ${ }^{238} \mathrm{U}-{ }^{232} \mathrm{Th}$-series and ${ }^{40} \mathrm{~K}$ has been determined. The average activity concentration of ${ }^{238} \mathrm{U},{ }^{232} \mathrm{Th}$ and ${ }^{40} \mathrm{~K}$ for marble samples was 23.77 $\mathrm{Bq} / \mathrm{kg}$ ranged from (10.91 to 45.4$), 10.75 \mathrm{~Bq} / \mathrm{kg}$ ranged from (5.46 to 23.61$)$ and $520.43 \mathrm{~Bq} / \mathrm{kg}$ ranged from (382.30 to $1132.41)$, respectively. The ${ }^{238} \mathrm{U},{ }^{232} \mathrm{Th}$ and ${ }^{40} \mathrm{~K}$ activity concentration for granite samples were $54.31 \mathrm{~Bq} / \mathrm{kg}$ ranged from (12.04 to 106.34$), 113.57 \mathrm{~Bq} / \mathrm{kg}$ ranged from (23.91 to 270.36$)$ and $7867.51 \mathrm{~Bq} / \mathrm{kg}$ ranged from (2017.60 to 11436.91), respectively. Concerning the radiological risk, the radium equivalent activity, external and internal radiation hazard indices, the radiation level index and absorbed dose rate were evaluated. The mass exhalation rates of ${ }^{222} \mathrm{Rn}$ and emanation coefficient have been also calculated. The mass exhalation rate of radon was found to be from 14.86 to 137.13 and 16.48 to $155.26 \mu \mathrm{Bq} / \mathrm{kg} \cdot \mathrm{s}$ for marble and granite samples, respectively. The mean values of the specific activity of ${ }^{226} \mathrm{Ra}$, activity of ${ }^{238} \mathrm{U}$ before and after sealing time and the mass exhalation rate of radon for granite samples are twice that for marble samples. All radiological indices and the mass exhalation rate of radon are lower than the permissible levels for building material in all marble samples, while all granite samples are higher and unsafe and pose a risk to the workers and users of these products due to the emanation of radon that may accumulate by time, especially in closed spaces.
\end{abstract}

Keywords: Radiological Hazards; Marble; Granite; HPGe Detector; Shak El Thouban

\section{Introduction}

Since the Earth formed and life developed, background radiation has been our constant companion. Primordial radionuclides are found around the globe in igneous and sedimentary rock. These radionuclides migrate from rocks into soil, water, and even air. Human activities such as uranium mining have also redistributed these radionuclides. Primordial radionuclides include the series of radionuclides produced when uranium and thorium decay, as well as potassium-40. Usually much attention is paid to ${ }^{226} \mathrm{Ra}$ due to ${ }^{222} \mathrm{Rn}$ exhalation and the subsequent internal exposure that a person constantly inhales. The specific activities of ${ }^{238} \mathrm{U},{ }^{232} \mathrm{Th}$ and ${ }^{40} \mathrm{~K}$ in building

*Corresponding author. raw materials (such as cement, brick, concrete, soil, marble, granite, sand, etc.) mainly depend on their geological sites of origin and their geochemical characteristics. Therefore, knowledge of radiation levels and basic radiological parameters in building materials is essential to assess possible risks to human health.

Over the past decade, a number of studies have been reported on the activity concentrations of natural radionuclides for marble and granite samples obtained from different countries in the world [1-7].

As a result of its geological location, Egypt possesses very rich natural stone (mainly marble and granite) reserves in various colors and patterns [8]. Natural stone has become the standard material used for many luxurious homes and high price apartments. Marble and gra- 
nite are used for cooking work places, bathrooms, entrance halls and living rooms. Accordingly there is a good demand for tiles, especially marble for interior flooring owing to its aesthetic features, whereas granite is chiefly used for exterior cladding and in the funerary art $[9,10]$.

The area of Shak El Thouban in Katameyya has become a conglomeration of around 400 factories constituting $60 \%$ to $70 \%$ of marble and granite factories in Egypt working in the marble and granite industry. More than two thousand workshops for complementary industries employ about 25 thousand workers other than 30 thousand workers indirect employment. Problems in these regions are outbreak of a group of diseases (e.g.: tinea, intestinal colic and chest disease) among workers in Shak El Thouban as a result of drinking water and food contamination. Marble and granite industry has stone waste in generally a highly polluting waste due to both its highly alkaline nature and its manufacturing and processing techniques, which impose a health threat to the surroundings. Shak El Thouban industrial cluster in Egypt is imposing an alarm threat to the surrounding communities, the new Maadi, Zahraa Elmaadi, residential area, and the ecology of the neighboring Wadi Degla protectorate.

The present study aims to determine the activity concentration of ${ }^{238} \mathrm{U},{ }^{232} \mathrm{Th}$ and ${ }^{40} \mathrm{~K}$ of twenty six marble and granite samples wide locally used at Shak El Thouban industrial zone in Egypt, using HPGe detector in a low background configuration. The results are used to assess the potential radiological hazards associated with these materials by computing the radium equivalent activity, radiation hazard indices and absorbed dose rate. The radon mass exhalation rate and the emanation coefficient were also determined and evaluated for all examined samples.

\section{Material and Methods}

\subsection{Sampling and Sample Preparation}

The area of Shak El Thouban industrial zone in Katameyya, Egypt has become a conglomeration of factories working in the marble and granite industries. Twenty six different types of marble, granite samples (nineteen samples of marble coded M1 to M19, seven samples of granite coded G20 to G26) were collected from different factories at Shak El Thouban industrial zone (Tables 1 and 2 , respectively).

Table 1. Average activity concentrations of ${ }^{238} \mathrm{U},{ }^{232} \mathrm{Th}$ and ${ }^{40} \mathrm{~K}$ for nineteen different marble samples used in Shak El Thouban, Egypt.

\begin{tabular}{|c|c|c|c|c|}
\hline Sample & Commercial name (Origin) & ${ }^{238} \mathrm{U} \mathrm{Bq} / \mathrm{kg}$ & ${ }^{232} \mathrm{Th} \mathrm{Bq} / \mathrm{kg}$ & ${ }^{40} \mathrm{~K} \mathrm{~Bq} / \mathrm{kg}$ \\
\hline M1 & Prashia (El-Aish, Egypt) & 14.63 & 9.41 & 453.89 \\
\hline M2 & Zafarana (Zafarana, Egypt) & 27.51 & 9.03 & 431.34 \\
\hline M3 & Serpagenty (El-Arish, Egypt) & 21.22 & 8.33 & 525.85 \\
\hline M4 & Sinai (RasGharbe, Egypt) & 30.47 & 9.42 & 534.46 \\
\hline M5 & Triesta (South Sinai, Egypt) & 11.09 & 5.46 & 602.64 \\
\hline M6 & Galala (Suez, Egypt) & 17.97 & 10.45 & 532.77 \\
\hline M7 & Golden Yellow (Egypt) & 15.04 & 6.88 & 478.13 \\
\hline M8 & Galala Extra (Suez, Egypt) & 23.84 & 7.71 & 515.05 \\
\hline M9 & Golden Beach (Egypt) & 15.76 & 8.54 & 692.08 \\
\hline M10 & Red marble (Turkey) & 13.04 & 8.46 & 449.70 \\
\hline M11 & Emperador (Spain) & 79.44 & 23.61 & 568.56 \\
\hline M12 & PerlatoSvevo (Italy) & 10.91 & 11.13 & 435.43 \\
\hline M13 & Weight marble (Turkey) & 18.08 & 10.08 & 435.79 \\
\hline M14 & Rosa (India) & 16.82 & 11.01 & 1132.41 \\
\hline M15 & Emperador (Lebanon) & 18.06 & 8.87 & 394.51 \\
\hline M16 & Crema (Turkey) & 15.78 & 8.20 & 463.05 \\
\hline M17 & Green marble (India) & 19.42 & 11.51 & 400.57 \\
\hline M18 & Emperador (Syria) & 45.40 & 19.61 & 382.30 \\
\hline M19 & Emperador Brown (China) & 37.23 & 16.63 & 459.69 \\
\hline Mean & & 23.77 & 10.75 & 520.43 \\
\hline P. L. & & 50 & 50 & 500 \\
\hline
\end{tabular}

P. L.: Permissible level. 
Table 2. Average activity concentrations of ${ }^{238} \mathrm{U},{ }^{232} \mathrm{Th}$ and ${ }^{40} \mathrm{~K}$ for seven different granite samples used in Shak El Thouban, Egypt.

\begin{tabular}{clccc}
\hline Sample & \multicolumn{1}{c}{ Commercial name (Origin) } & ${ }^{238} \mathbf{U} \mathbf{~ B q} / \mathbf{k g}$ & ${ }^{232} \mathbf{T h ~ B q} / \mathbf{k g}$ & ${ }^{{ }^{40} \mathbf{K ~ B q} / \mathbf{k g}}$ \\
\hline $\mathbf{G 2 0}$ & Ghandola (Aswan, Egypt) & 106.34 & 142.73 & 9175.02 \\
$\mathbf{G 2 1}$ & Red Granite (Aswan, Egypt) & 40.45 & 108.14 & 11436.91 \\
$\mathbf{G 2 2}$ & Red Gharda (Ghardaqah, Egypt) & 91.35 & 270.36 & 10820.41 \\
$\mathbf{G 2 3}$ & Black Aswan (Aswan, Egypt) & 12.04 & 23.91 & 2017.60 \\
$\mathbf{G 2 4}$ & Ghazal Dark (Aswan, Egypt) & 38.70 & 129.13 & 9734.34 \\
$\mathbf{G 2 5}$ & Tan Brown Granite (India) & 58.72 & 82.70 & 8447.16 \\
G26 & Black Granite (India) & 32.56 & 37.99 & 3441.16 \\
Mean & & 54.31 & 113.57 & 7867.51 \\
P. $\mathbf{L}$. & & 50 & 50 & 500 \\
\hline
\end{tabular}

P. L.: Permissible level.

The samples were crushed, dried and sieved through 200 mesh size. Weighted samples were placed in polyethylene bottles of $250 \mathrm{~cm}^{3}$ volume. The bottles were completely sealed for more than one month to allow radioactive equilibrium to be reached between ${ }^{238} \mathrm{U}$ and

${ }^{232} \mathrm{Th}$ and their corresponding daughters to be measured by gamma spectrometry. This step was necessary to ensure that radon gas is confined within the volume and the daughters will also remain in the sample.

\subsection{Experimental Method for Gamma Spectroscopy}

The detection system consists of an ORTEC hyper pure germanium (HPGe) detector of sensitive volume of 76.11 $\mathrm{cm}^{3}$, preamplifier, spectroscopy amplifier, high voltage power supply and the multichannel analyzer. The HPGe detector has a full width at half maximum of $0.9 \mathrm{keV}$ at the $122 \mathrm{keV}$ gamma transition of ${ }^{57} \mathrm{Co}$ and $1.85 \mathrm{keV}$ at $1332.5 \mathrm{keV}$ of ${ }^{60} \mathrm{Co}$ gamma transition with photopeak efficiency $30 \%$. To reduce the gamma-ray background, a cylindrical lead shield with a fixed bottom and a movable cover shielded the detector. The lead shield contained two inner concentric cylinders of copper and cadmium to prevent interference X-rays by lead. The energy calibration of the HPGe spectrometer was carried out by using standard point sources $\left({ }^{60} \mathrm{Co},{ }^{133} \mathrm{Ba},{ }^{137} \mathrm{Cs},{ }^{226} \mathrm{Ra}\right.$ and $\left.{ }^{241} \mathrm{Am}\right)$. Absolute efficiency calibration curves are calculated for activity determination of the sample by using standard ${ }^{238} \mathrm{U}$ and ${ }^{232} \mathrm{Th}$ with activities of 2120.37 and $1333.96 \mathrm{~Bq}$, respectively and potassium chloride $\mathrm{KCl}$ solutions with activity $15.9 \mathrm{~Bq}$ [11], contained in the same cylindrical bottles with the same volume $250 \mathrm{~cm}^{3}$ and having the same nature as the investigated samples. The standards and the samples were prepared with a uniform geometry. In order to determine the background distribution in the environment around the detector, an empty bottle was counted in the same manner and ge- ometry as the samples. The background spectra were used to correct the areas of gamma rays for measured isotopes. The quality assurance of the measurements was carried out by a daily energy and efficiency calibrations and repeating each sample measurements. Each sample was analyzed for a time of 70,000 seconds to obtain the gamma-ray spectrum with good statistics. The gamma emitting radionuclide specifically recorded was ${ }^{238} \mathrm{U}$, ${ }^{226} \mathrm{Ra},{ }^{232} \mathrm{Th}$ and ${ }^{40} \mathrm{~K}$.

The ${ }^{238} \mathrm{U}$ radionuclide was estimated from the 351.9 $\mathrm{keV}(36.7 \%)$ and $295.2 \mathrm{keV}(13.3 \%)$ gamma peaks of ${ }^{214} \mathrm{~Pb}$ and $609.3 \mathrm{keV}(46.1 \%), 1120.3 \mathrm{keV}(15 \%)$, and $1764 \mathrm{keV}(15.9 \%)$ gamma peaks of ${ }^{214} \mathrm{Bi} .{ }^{232} \mathrm{Th}$ radionuclide was estimated from the $338.6 \mathrm{keV}(11.27 \%)$ and $911.1 \mathrm{keV}(29 \%)$ gamma peaks of ${ }^{228} \mathrm{Ac}$ and $583.1 \mathrm{keV}$ $(84.5 \%)$ and $2614.7 \mathrm{keV}(9.9 \%)$ gamma peaks of ${ }^{208} \mathrm{Tl}$. The ${ }^{226} \mathrm{Ra}$ concentration was measured from its gammaray peak at $186.1 \mathrm{keV} .{ }^{40} \mathrm{~K}$ radionuclide was estimated using $1460.8 \mathrm{keV}$ (10.7\%) gamma peak from ${ }^{40} \mathrm{~K}$ itself to determine the concentration of ${ }^{40} \mathrm{~K}$ in different samples.

\section{Results and Discussion}

Activity concentrations (in $\mathrm{Bq} / \mathrm{kg}$ ) of naturally occurring radionuclides isotopes reported in each of the ${ }^{238} \mathrm{U}$-series and ${ }^{232} \mathrm{Th}$-series in the marble and granite used at Shak El Thouban industrial zone in Egypt have been determined. The activity concentration values of ${ }^{226} \mathrm{Ra},{ }^{214} \mathrm{Bi}$ and ${ }^{214} \mathrm{~Pb}$ for ${ }^{238} \mathrm{U}$ were found to be 17.99 to $163.58 \mathrm{~Bq} / \mathrm{kg}$, 10.54 to $73.13 \mathrm{~Bq} / \mathrm{kg}$ and 3.96 to $82.31 \mathrm{~Bq} / \mathrm{kg}$, respectively. Similarly for ${ }^{232} \mathrm{Th}$ the activity concentration values of ${ }^{228} \mathrm{Ac}$ were varied from 8.87 to $96.68 \mathrm{~Bq} / \mathrm{kg}$ and ${ }^{208} \mathrm{Tl}$ were varied from 4.56 to $84.01 \mathrm{~Bq} / \mathrm{kg}$.

The average activity concentrations in marble samples were found to be $23.77 \mathrm{~Bq} / \mathrm{kg}$ ranged from10.91 to 45.40 $\mathrm{Bq} / \mathrm{kg}$ for ${ }^{238} \mathrm{U}, 10.75 \mathrm{~Bq} / \mathrm{kg}$ ranged from 5.46 to 23.61 $\mathrm{Bq} / \mathrm{kg}$ for ${ }^{232} \mathrm{Th}$ and $520.43 \mathrm{~Bq} / \mathrm{kg}$ ranged from 382.30 to 
$1132.41 \mathrm{~Bq} / \mathrm{kg}$ for ${ }^{40} \mathrm{~K}$, as reported in Table 1. The activity concentrations in granite samples were varied from 12.04 to $106.340 \mathrm{~Bq} / \mathrm{kg}$ with a mean value $55.31 \mathrm{~Bq} / \mathrm{kg}$ for ${ }^{238} \mathrm{U}, 23.91$ to $270.36 \mathrm{~Bq} / \mathrm{kg}$ with a mean value $113.57 \mathrm{~Bq} / \mathrm{kg}$ for ${ }^{232} \mathrm{Th}$ and 2017.60 to $11436.91 \mathrm{~Bq} / \mathrm{kg}$ with a mean value $7867.51 \mathrm{~Bq} / \mathrm{kg}$ for ${ }^{40} \mathrm{~K}$, as reported in Table 2. It is clear that the activity concentrations of ${ }^{238} \mathrm{U}$, ${ }^{232} \mathrm{Th}$ and ${ }^{40} \mathrm{~K}$ in marble samples are within the permissible levels 50,50 and $500 \mathrm{~Bq} / \mathrm{kg}$ [12], while that in granite samples are higher than the permissible levels.

Studies were performed between the combinations of radionuclides like ${ }^{238} \mathrm{U}$ and ${ }^{226} \mathrm{Ra}$ as well as ${ }^{238} \mathrm{U}$ and ${ }^{232} \mathrm{Th}$ activity concentrations. Figure 1 represents the relation between $\left({ }^{238} \mathrm{U},{ }^{226} \mathrm{Ra}\right)$ as well as $\left({ }^{238} \mathrm{U},{ }^{232} \mathrm{Th}\right)$ activities for marble and granite samples under investigation. Strong correlations were observed between ${ }^{238} \mathrm{U}$ and $\left.{ }^{226} \mathrm{Ra}\right)$ with $\left(\mathrm{R}^{2}=0.95, \mathrm{~N}=19\right)$ for marble samples and with $\left(R^{2}=0.995, N=7\right)$ for granite samples which

$$
\begin{aligned}
& \text { Correlation between }{ }_{\text {samples }}^{238} \mathrm{U} \text { and }{ }^{226} \mathrm{Ra} \text { formarble } \\
& \text {. }
\end{aligned}
$$

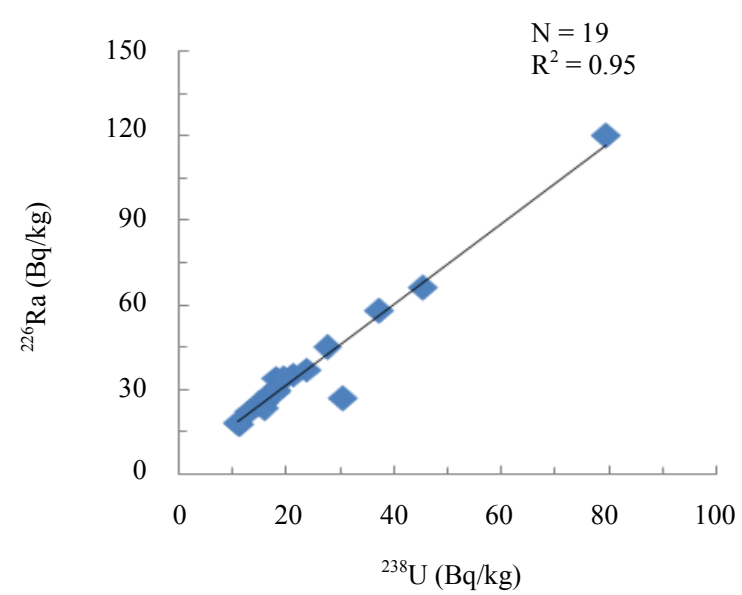

Correlation between ${ }^{238} \mathrm{U}$ and ${ }^{226} \mathrm{Ra}$ for granite
samples

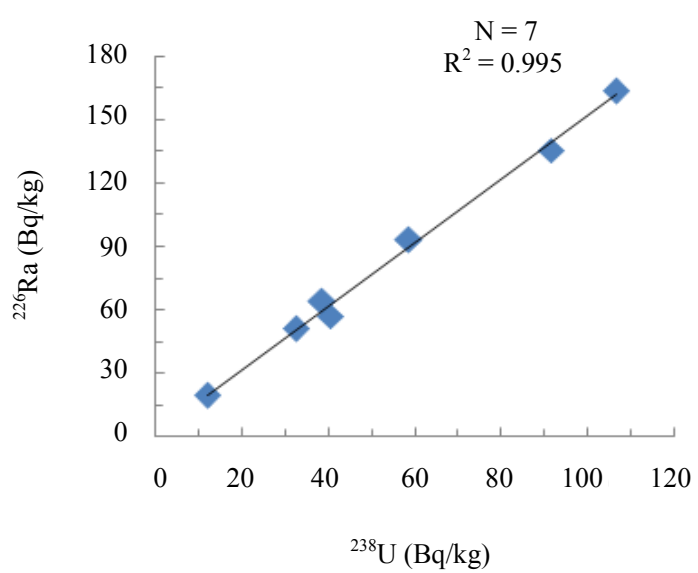

clear the radioactive equilibrium in uranium series. Similarly, moderate correlation were also observed between $\left({ }^{238} \mathrm{U}\right.$ and $\left.{ }^{232} \mathrm{Th}\right)$ with $\left(\mathrm{R}^{2}=0.78, \mathrm{~N}=19\right)$ for marble samples and with $\left(\mathrm{R}^{2}=0.57, \mathrm{~N}=7\right)$ for granite samples due to the high activity concentration of ${ }^{238} \mathrm{U}$ than ${ }^{232} \mathrm{Th}$.

Assessment of radiological hazards was made by calculating the radium equivalent activities, external and internal hazard indices. The radium equivalent activity $\left(\mathrm{Ra}_{\mathrm{eq}}\right)$ is a weighted sum of activities of the ${ }^{226} \mathrm{Ra},{ }^{232} \mathrm{Th}$ and ${ }^{40} \mathrm{~K}$ based on the assumption that $370 \mathrm{~Bq} / \mathrm{kg}$ of Ra, $259 \mathrm{~Bq} / \mathrm{kg}$ of $\mathrm{Th}$ and $4810 \mathrm{~Bq} / \mathrm{kg}$ of $\mathrm{K}$ produce the same gamma-ray dose rates as given by the following equation [13]:

$$
\mathbf{R a}_{\mathrm{eq}}=\mathrm{A}_{\mathrm{Ra}}+1.43 \mathrm{~A}_{\mathrm{Th}}+0.077 \mathrm{~A}_{\mathrm{K}}
$$

The results obtained for the radium equivalent activity index $\mathbf{R} \mathbf{a}_{\mathrm{eq}}$ of all samples of marble and granite are varied from 59.77 to $156.89 \mathrm{~Bq} / \mathrm{kg}$ and from 201.58 to 1311.14

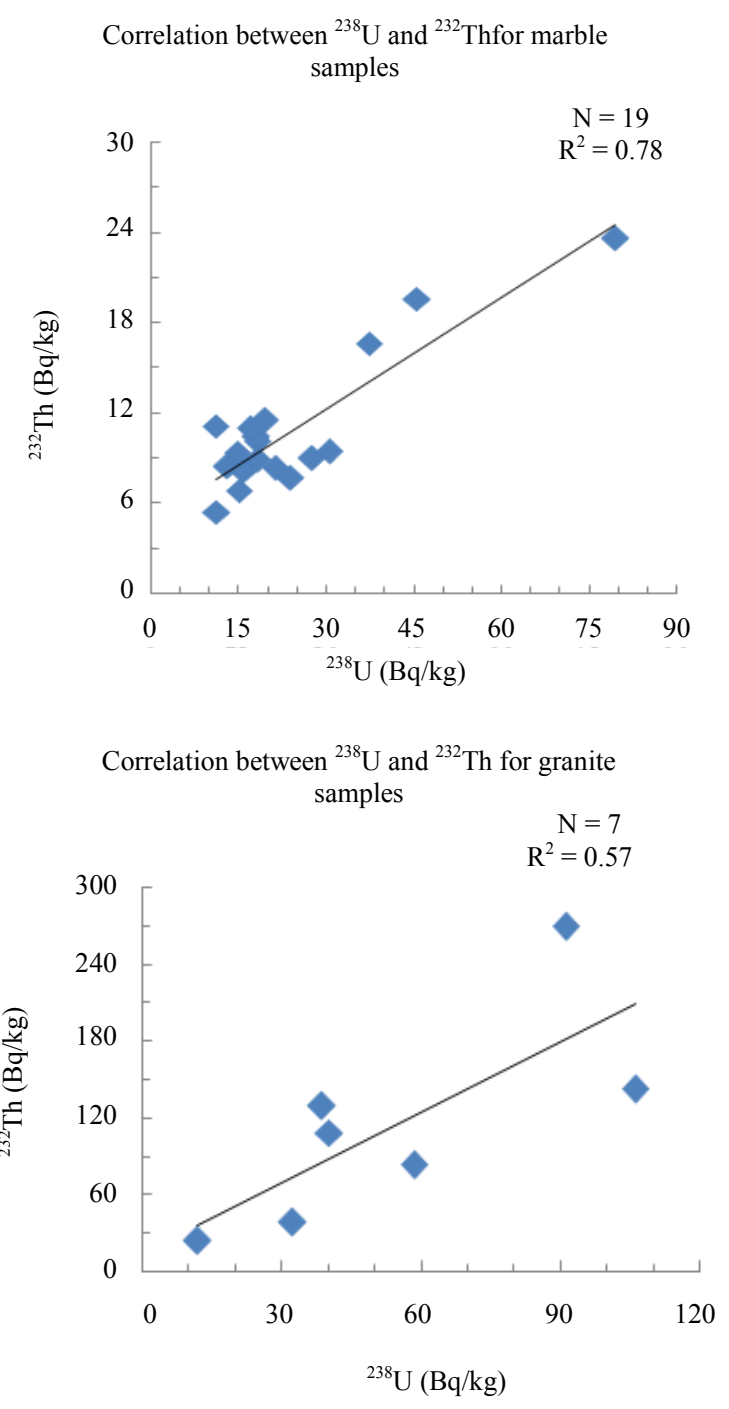

Figure 1. Correlation between $\left({ }^{238} \mathrm{U},{ }^{226} \mathrm{Ra}\right)$ and $\left({ }^{238} \mathrm{U},{ }^{232} \mathrm{Th}\right)$ concentrations for samples under investigation. 
$\mathrm{Bq} / \mathrm{kg}$ respectively as listed in Table 3. It is observed that the values of radium equivalent index of all marble samples and black granite samples (G23 and G26) are lower than the recommended value $370 \mathrm{~Bq} / \mathrm{kg}$ [14] while the other granite samples are higher than the recommended value.

The other factors indicating radiological hazards are external $\left(\mathrm{H}_{\mathrm{ex}}\right)$ and internal $\left(\mathrm{H}_{\mathrm{in}}\right)$ hazard indices which measure the radiation exposure due to the radioactivity and defined by the following equations $[15,16]$ :

$$
\begin{aligned}
& H_{\text {ex }}=A_{\text {Ra }} / \mathbf{3 7 0}+A_{\text {Th }} / \mathbf{2 5 9}+A_{K} / 4810 \\
& H_{\text {int }}=A_{\text {Ra }} / \mathbf{1 8 5}+A_{\text {Th }} / \mathbf{2 5 9}+A_{k} / 4810
\end{aligned}
$$

$A_{R a}, A_{T h}$, and $A_{K}$ are the activity concentration (in $\mathrm{Bq} / \mathrm{kg}$ ) of ${ }^{226} \mathrm{Ra},{ }^{232} \mathrm{Th}$ and ${ }^{40} \mathrm{~K}$, respectively. In order to keep the radiation hazards to be insignificant, the value of $\mathrm{H}_{\mathrm{ex}}$ and $\mathrm{H}_{\mathrm{int}}$ must be less than unity $[17,18]$.

The external and internal hazard indices of marble samples are varied from 0.16 to 0.42 and 0.19 to 0.64 $\mathrm{mGy} / \mathrm{yr}$, respectively and that of granite samples are varied from 0.54 to 3.54 and 0.58 to $3.79 \mathrm{mGy} / \mathrm{yr}$, respectively as listed in Table 3. It is noticed that external and internal hazards indices are lower than unity for all marble and black granite samples (G23 and G26) while the other granite samples are higher than unity.

To estimate the level of $\gamma$-radiation hazard associated

Table 3. The values of radium equivalent, external and internal hazard indices, radioactivity level index and dose rate for

\begin{tabular}{|c|c|c|c|c|c|}
\hline Sample & $\mathrm{Ra}_{\mathrm{eq}} \mathrm{Bq} / \mathrm{kg}$ & $H_{e x} m G y / y$ & $\mathbf{H}_{\text {in }} \mathbf{m G y} / \mathbf{y}$ & $\mathbf{I}_{\gamma}$ & Dose rate $\mathrm{nGy} / \mathrm{h}$ \\
\hline M1 & 63.03 & 0.17 & 0.21 & 0.50 & 31.99 \\
\hline M2 & 73.64 & 0.20 & 0.27 & 0.56 & 36.27 \\
\hline M3 & 73.62 & 0.20 & 0.26 & 0.58 & 37.18 \\
\hline M4 & 85.10 & 0.23 & 0.31 & 0.66 & 42.23 \\
\hline M5 & 65.30 & 0.18 & 0.21 & 0.53 & 34.26 \\
\hline M6 & 73.94 & 0.20 & 0.25 & 0.58 & 37.50 \\
\hline M7 & 61.69 & 0.17 & 0.21 & 0.49 & 31.54 \\
\hline M8 & 74.52 & 0.20 & 0.27 & 0.58 & 37.43 \\
\hline M9 & 81.26 & 0.22 & 0.26 & 0.65 & 42.14 \\
\hline M10 & 59.77 & 0.16 & 0.20 & 0.47 & 30.51 \\
\hline M11 & 156.98 & 0.42 & 0.64 & 1.05 & 74.00 \\
\hline M12 & 60.36 & 0.16 & 0.19 & 0.48 & 30.75 \\
\hline M13 & 66.04 & 0.18 & 0.23 & 0.51 & 33.13 \\
\hline M14 & 119.76 & 0.32 & 0.37 & 0.98 & 63.16 \\
\hline M15 & 61.12 & 0.17 & 0.21 & 0.47 & 30.55 \\
\hline M16 & 63.16 & 0.17 & 0.21 & 0.50 & 32.08 \\
\hline M17 & 66.72 & 0.18 & 0.23 & 0.51 & 33.13 \\
\hline M18 & 102.88 & 0.28 & 0.40 & 0.76 & 48.81 \\
\hline M19 & 96.41 & 0.26 & 0.36 & 0.72 & 46.68 \\
\hline G20 & 1016.92 & 2.75 & 3.03 & 8.29 & 534.42 \\
\hline G21 & 1075.74 & 2.90 & 3.01 & 9.02 & 580.65 \\
\hline G22 & 1311.14 & 3.54 & 3.79 & 10.57 & 683.26 \\
\hline G23 & 201.58 & 0.54 & 0.58 & 1.67 & 107.72 \\
\hline G24 & 972.90 & 2.63 & 2.73 & 8.07 & 520.59 \\
\hline G25 & 827.41 & 2.23 & 2.39 & 6.88 & 443.05 \\
\hline G26 & 351.85 & 0.95 & 1.04 & 2.90 & 187.02 \\
\hline P. L. & 370 & $<1$ & $<1$ & $<1$ & 55 \\
\hline
\end{tabular}
marble and granite samples under investigation.

P. L.: Permissible level. 
with the natural radionuclides another radiation level index suggested by OECD's NEA [19] are evaluated using the following equation:

$$
\mathbf{I}_{\gamma}=\mathbf{A}_{\mathrm{Ra}} / \mathbf{1 5 0}+\mathbf{A}_{\mathrm{Th}} / \mathbf{1 0 0}+\mathbf{A}_{\mathbf{k}} / \mathbf{1 5 0 0}
$$

$\mathrm{A}_{\mathrm{Ra}}, \mathrm{A}_{\mathrm{Th}}$, and $\mathrm{A}_{\mathrm{K}}$ are the activity concentration (in $\mathrm{Bq} /$ $\mathrm{kg}$ ) of ${ }^{226} \mathrm{Ra},{ }^{232} \mathrm{Th}$ and ${ }^{40} \mathrm{~K}$, respectively. The radiation level index $\mathrm{I}_{\gamma}$ of marble and granite samples are varied from 0.47 to 1.05 and from 1.67 to 10.57 , respectively which is found to be less than unity for all marble samples and higher than unity for all granite samples, as listed in Table 3.

The absorbed dose rate in air express the received dose in the open air from the radiation emitted from radionuclides activity concentrations in the environmental materials. This factor is important quantity to assess when considering radiation risk to a bio system. The absorbed dose rate, $\mathrm{D}(\mathrm{nGy} / \mathrm{h})$ in air at $1 \mathrm{~m}$ above the ground level owing to the concentration of ${ }^{238} \mathrm{U},{ }^{232} \mathrm{Th}$ and ${ }^{40} \mathrm{~K}[15,20]$ is given by:

$$
\mathrm{D}=0.4299 \mathrm{~A}_{\mathrm{U}}+0.666 \mathrm{~A}_{\mathrm{Th}}+0.042 \mathrm{~A}_{\mathrm{K}}
$$

$A_{R a}, A_{T h}$, and $A_{K}$ are the activity concentration (in $\mathrm{Bq} / \mathrm{kg}$ ) of ${ }^{226} \mathrm{Ra},{ }^{232} \mathrm{Th}$ and ${ }^{40} \mathrm{~K}$, respectively.

The absorbed dose rate for samples under investigation varied from 30.51 to 74.00 with mean value $39.65 \mathrm{nGy} / \mathrm{h}$ for marble and from 107.72 to 683.26 with mean value $436.67 \mathrm{nGy} / \mathrm{h}$ for granite, as presented in Table 3. It is clear that its values are lower than the recommended value $55 \mathrm{nGy} / \mathrm{h}$ for all marble samples except marble sample M11 and all granite samples.

The mass exhalation rate $\left(\mathrm{E}_{\mathrm{Rn}}\right)$ and emanation rate coefficient of radon $\left(\mathrm{C}_{\mathrm{Rn}}\right)$ that can diffuse through the raw and building materials is also a very important radiological index used to evaluate the amount of the ${ }^{222} \mathrm{Rn}$ emanation fraction released from the building raw materials and products containing naturally occurring radionuclides such as ${ }^{222} \mathrm{Rn}$ in radioactive equilibrium with its parent. The emanation coefficient of radon $\left(\mathrm{C}_{\mathrm{Rn}}\right)$ was determined [21] according to:

$$
\mathrm{C}_{\mathrm{Rn}}=\mathrm{C} /\left(\mathrm{C}_{\mathbf{0}}+\mathrm{C}\right)
$$

$\mathrm{C}_{0}$ and $\mathrm{C}$ are the net count rate of radon at the sealing time of the samples and after equilibrium (after 30 days), respectively.

The mass exhalation rate of radon is the product of the emanation coefficient of radon $\left(\mathrm{E}_{\mathrm{Ra}}\right)$ and production rate of radon [21]. The mass exhalation rate $\left(E_{R n}\right.$ in $\left.\mathrm{Bq} / \mathrm{kg} \cdot \mathrm{s}\right)$ is determined using the following equation:

$$
\mathbf{E}_{\mathrm{Rn}}=\mathbf{C}_{\mathrm{Rn}} \mathbf{A}_{\mathrm{Ra}} \lambda_{\mathrm{Rn}}
$$

$\mathrm{A}_{\mathrm{Ra}}$ is the specific activity of ${ }^{226} \mathrm{Ra}$ (in $\mathrm{Bq} / \mathrm{kg}$ ) and $\lambda_{\mathrm{Rn}}$ is the decay constant of ${ }^{222} \mathrm{Rn}\left(\lambda_{\mathrm{Rn}}=2.1 \times 10^{-6} \mathrm{~s}^{-1}\right)$.

The mean value of the emanation coefficient $C_{R n}$ and the ${ }^{222} \mathrm{Rn}$ mass exhalation rate $\mathrm{E}_{\mathrm{Rn}}$ of the samples under investigation are listed in Table 4. It is clear that the values of the emanation coefficient and the ${ }^{222} \mathrm{Rn}$ exhaletion rate for all samples under investigation were ranged

Table 4. The specific activity of ${ }^{226}$ Ra, activity of ${ }^{238} \mathrm{U}$ before and after sealing time, the emanation coefficient and the radon mass exhalation rate for marble and granite samples under investigation.

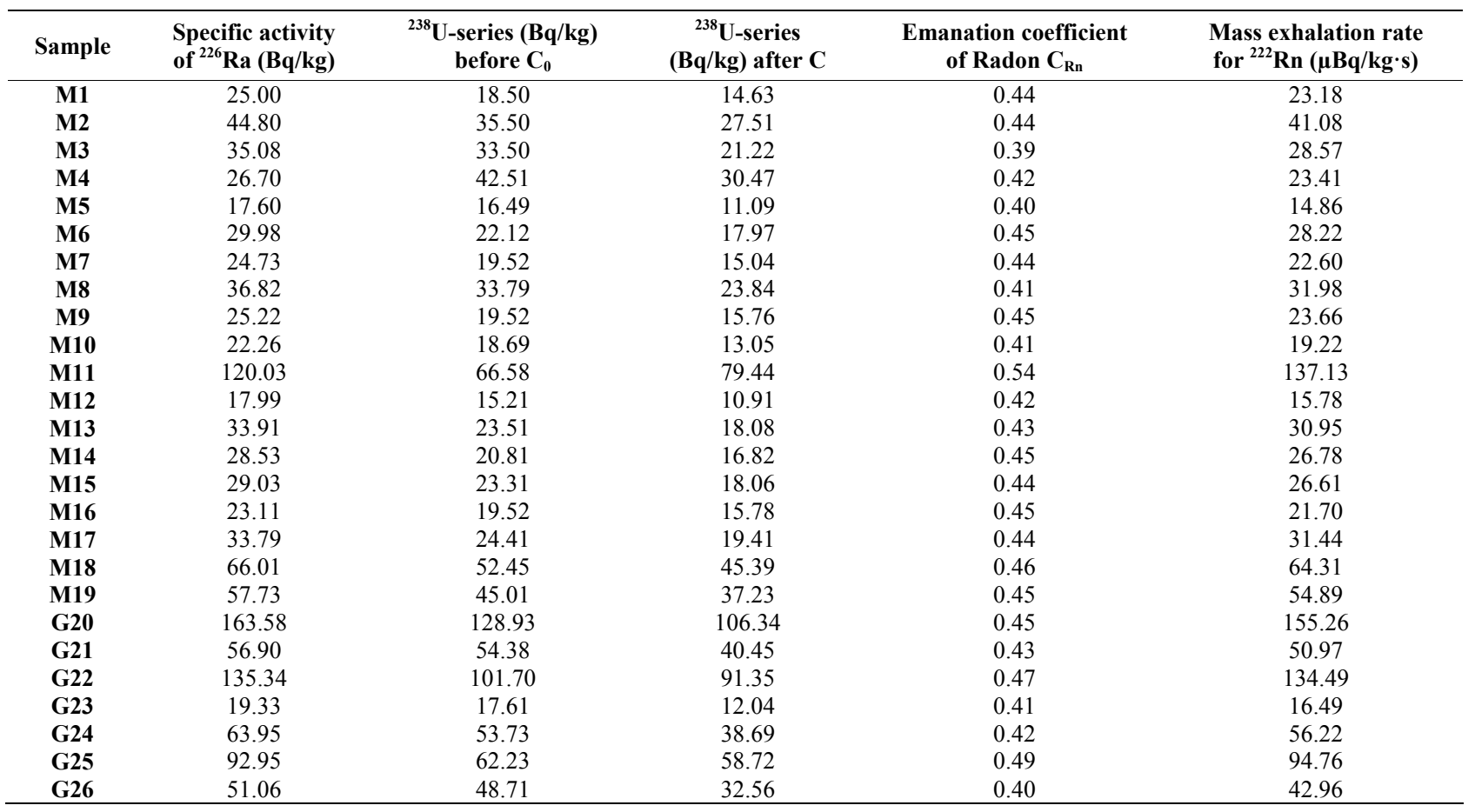


from 0.39 to 0.54 and 14.86 to $155.26 \mu \mathrm{Bq} /(\mathrm{kg} \cdot \mathrm{s})$, respectively. The mass exhalation rate of ${ }^{222} \mathrm{Rn}$ in marble and granite were varied from 14.86 to 137.13 and 16.48 to $155.26 \mu \mathrm{Bq} / \mathrm{kg} \cdot \mathrm{s}$, respectively.

Figure 2 shows a strong correlation between the specific activity of ${ }^{226} \mathrm{Ra}$ and ${ }^{222} \mathrm{Rn}$ mass exhalation rate with $\left(\mathrm{R}^{2}=0.986, \mathrm{~N}=26\right)$ for marble and granite samples, which means that ${ }^{222} \mathrm{Rn}$ and ${ }^{226} \mathrm{Ra}$ accompanied each other and that the individual result for any one of the radionuclide concentration is a good predictor of the concentration of the other.

\section{Conclusions}

Environmental monitoring should be carried out for marbles and granites used at Shak El Thouban industrial zone in Katameyya, Egypt where people might be exposed to radioactivity. The levels of natural radioactivity in marble and granite samples were determined using high resolution gamma-ray spectrometry. The results can be useful in the assessment of the radiological hazard associated with the exposures and the radiation doses due to naturally radioactive element contents in marble and granite samples. We noticed that there is a strong correlation between radium-226 and uranium-238 in marbel and granite samples which means that the two elements accompanied each other. Also, there is a strong correlation between the specific activity of radium and radon mass exhalation rate, so the knowledge of uranium concentrations gives a good estimate of the radon concentrations in the samples and its escape to the atmosphere.

The present study showed that the measured marble samples were within the recommended safety limits and did not pose any significant source of radiation hazard inhabitants. It is also clear that, the high activity concentration, radioactive level and mass exhalation rate of the radon within most granite samples pose a radiation hazard to the workers and users of the this product and cause a great effect on the humans health, especially those working in closed spaces since the emanated radon may

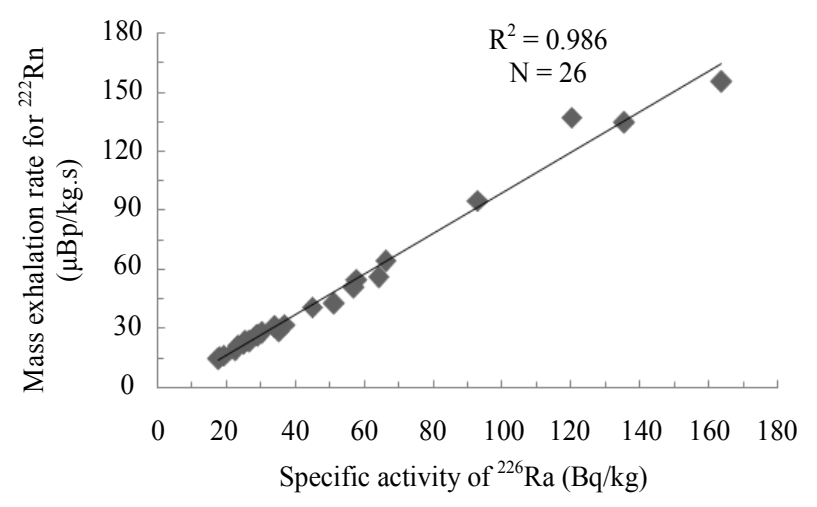

Figure 2. Mass exhalation rate for ${ }^{222} \mathrm{Rn}$ verses specific activity of ${ }^{226} \mathrm{Ra}$ for all samples under investigation. be accumulated by time. Therefore, safety rules and precautions should be necessary for workers and users of granite types, especially in closed spaces.

\section{REFERENCES}

[1] U. Cevic, N. Damla, A. I. Kobya, A. Celik and A. Kara, "Radiation Dose Estimation and Mass Attenuation Coefficients of Marble Used in Turkey," Annals of Nuclear Energy, Vol. 37, No. 12, 2010, pp. 1705-1711. http://dx.doi.org/10.1016/j.anucene.2010.07.011

[2] D. Malczewski, L. Teper and J. Dorda, "Assessment of Natural and Anthropogenic Radioactivity Levels in Rocks and Soils in the Environs of Swieradow Zdroj in Sudetes, Poland, by in Situ Gamma-Ray Spectrometry," Journal of Environmental Radioactivity Vol. 73, No. 3, 2004, pp. 233-245. http://dx.doi.org/10.1016/j.jenvrad.2003.08.010

[3] T. A. Myatt, J. G. Allen, T. Minegishi, W. B. Mccarthy, J. H. Stewart, D. L. Macintosh and J. F. Mccarthy, "Assessing Exposure to Granite Countertops-Part 1, Radiation," Journal of Exposure Science and Environmental Epidemiology, Vol. 20, No. 3, 2010, pp. 273-280. http://dx.doi.org/10.1038/jes.2009.44

[4] Y. Örgün, N. Altinsoy, A. H. Gültekin, G. Karahan and N. Celebi, "Natural Radioactivity Levels in Granitic Plutons and Groundwaters in Southeast Part of Eskisehir, Turkey," Applied Radiation and Isotopes, Vol. 63, No. 2, 2005, pp. 267-275. http://dx.doi.org/10.1016/j.apradiso.2005.03.008

[5] A. T. Przylibski, "Concentration of ${ }^{226} \mathrm{Ra}$ in Rocks of the Southern Part of Lower Silesia," Journal of Environmental Radioactivity, Vol. 75, No. 2, 2004, pp. 171-191. http://dx.doi.org/10.1016/j.jenvrad.2003.12.003

[6] N. Walley El-Dine, A. El-Shershaby, F. Ahmed and A. S. Abdel-Haleem, "Measurement of Radioactivity and Radon Exhalation Rate in Different Kinds of Marbles and Granites," Applied Radiation and Isotopes, Vol. 55, No. 6, 2001, pp. 853-860.

http://dx.doi.org/10.1016/S0969-8043(01)00107-5

[7] M. S. Yasir, A. Abd Majid and R. Yahaya, "Study of Natural Radionuclides and Its Radiation Hazard Index in Malaysian Building Materials," Journal of Radioanalytical and Nuclear Chemistry, Vol. 273, No. 3, 2007, pp. 539-541. http://dx.doi.org/10.1007/s10967-007-0905-7

[8] R. Ciccu, R. Cosentino, C. Montani, A. El Kotb and H. Hamdy, "Strategic Study on the Egyptian Marble and Granite Sector," Industrial Modernisation Centre (IMC), Cairo, 2005.

[9] T. H. Selim and A. I. Kandil, "Characteristics of Marble Industry in Egypt: Structure, Conduct and Performance," International Business and Economics Research Journal, Vol. 5, No. 1, 2006, pp. 25-34.

[10] IAEA, "Preparation and Certification of IAEA Gamma Spectrometry Reference Materials, RGU-1, RGTH-1 and RGK-1," International Atomic Energy Agency, ReportIAEA/RL/148, 1987.

[11] UNSCEAR, "Sources and Effects of Ionizing Radiation," United Nations, New York, 1993.

[12] A. G. E. Abbady, "Estimation of Radiation Hazard Indi- 
ces from Sedimentary Rock in Upper Egypt," Applied Radiation and Isotope, Vol. 60, No. 1, 2004, pp. 111-114. http://dx.doi.org/10.1016/i.apradiso.2003.09.012

[13] UNSCEAR, "Sources and Effects and Risks of Ionizing Radiation," Report to the General Assembly, with Scientific Annexes, United Nations, New York, 2000.

[14] A. M. El Arabi, A. G. E. Abbady and A. S. Hussein, "Gamma-Ray Measurements of Natural Radioactivity in Sedimentary Rocks from Egypt," Nuclear Science and Techniques, Vol. 17, No. 2, 2006, pp. 123-128. http://dx.doi.org/10.1016/S1001-8042(06)60024-9

[15] M. Tufail, N. Akhter and M. Wqes, "Measurement of Terrestrial Radiation for Assessment of Gamma Dose from Cultivated and Barren Saline Soils of Faisalabad in Pakistan," Radiation Measurements, Vol. 41, No. 4, 2006, pp. 443-451. http://dx.doi.org/10.1016/j.radmeas.2005.01.007

[16] N. M. Ibrahim, B. El Ezaby, N. Nada, T. M. Abd ElMakasoud and S. N. Abd El Azem, "Radioactivity Concentration in Some Industrial Ores and Their Waste Products by Gamma Spectrometry," The 7th Conference of Nuclear Physics and Application, Cairo, 2000, pp. 6-10.

[17] A. Nada, "Gamma Spectroscopic Analysis for Estimation of Natural Radioactivity Levels in Some Granite Rocks of Eastern Desert, Egypt," Cairo Arab Journal of Nuclear
Science and Application, Vol. 37, No. 2, 2004, pp. 201222.

[18] OECD Organization of Economic Cooperation and Development, "Exposure to Radiation from Natural Radioactivity in Building Materials," Report by a Group of Experts of the OECD Nuclear Energy Agency, OECD, Paris, 1979.

[19] T. R. Ajayi and O. O. Kuforiji, "Natural Radioactivity Measurement in Rock Samples of Ondo and Ekiti States in Nigeria," Radiation Measurements, Vol. 33, No. 1, 2000, pp. 13-16. http://dx.doi.org/10.1016/S1350-4487(00)00092-5

[20] G. J. White and A. S. Road, "Radon Emanation from NORM Contaminated Pipe Scale and Soil at Petroleum Industry Sites," Journal of Environmental Radioactivity, Vol. 54, No. 3, 2001, pp. 401-13. http://dx.doi.org/10.1016/S0265-931X(00)00156-9

[21] M. I. Chowdhury, M. N. Alam and K. S. Ahmed, "Concentration of Radionuclides in Building and Ceramic Materials of Bangladish and Evaluation of Radiation Hazard," Journal of Radioanalytical Nuclear Chemistry, Vol. 231, No. 1-2, 1998, pp. 117-122. http://dx.doi.org/10.1007/BF02388016 